\title{
ASPEK INTERPRETASI PADA IMPLEMENTASI KEBIJAKAN PEMBERIAN IZIN MENDIRIKAN BANGUNAN OLEH BADAN PELAYANAN PERIZINAN TERPADU KOTA MANADO
}

\author{
William Agustinus Areros \\ Jurusan Administrasi Fakultas Ilmu Sosial dan Ilmu Politik Universitas Sam Ratulangi \\ E-mail: willyareros@gmail.com
}

\begin{abstract}
Penelitian ini diarahkan pada pengungkapan makna dibalik permasalahan pemahaman aspek interpretasi dalam implementasi kebijakan pemberian izin mendirikan bangunan yang dilakukan oleh Badan Pelayanan Perizinan Terpadu Kota Manado guna memperkaya khasana keilmuan khususnya konsep teori implementasi kebijakan serta menjadi rekomendasi kepada stackholder dalam implementasi kebiajakan pemberian izin mendirikan bangunan.dengan menggunakan metode penelitian kualitatif ditemukan bahwa aspek interpretasi dalam implementasi pemberian izin mendrikan bangunan pada Badan Pelayanan Perizinan TerpaduKota Manado berkaitan dengan indikator pemaknaan atas kebijakan, program dan kegiatan. Kemudahan aparatur menginterpretasi isi kebijakan sangat berkaitan dengan kualitas sumber daya yang dimiliki baik dari pendidikan, pengalaman maupun keahlian oleh para implementor.
\end{abstract}

Kata Kunci : Interpretasi, Implementasi Kebijakan, Izin Mendirikan Bangunan.

\section{INTERPRETATION OF POLICY IMPLEMENTATION ASPECTS OF BUILDING PERMITS BY GIVING SERVICES LICENSING AGENCY INTEGRATED CITY OF MANADO}

Abstract This research is directed at understanding the disclosure of the meaning behind the problems in the interpretation of aspects of policy implementation granting building permits were conducted by the Integrated Licensing Service Manado to enrich scientific theories, especially the concept of policy implementation as well as a recommendation to stackholder in policy implementation granting building permits.By using the method of qualitative research found that aspects of the interpretation in the implementation of the provision of building permits in the Integrated Licensing Service Agency Manado meaning of the indicators related to policies, programs and activities. Ease of apparatus to interpret the content of the policy is related to the quality of its resources both from the education, experience and expertise by the implementor.

Keywords: Interpretation, Policy Implementation, Building Permit.

\section{PENDAHULUAN}

Tugas pemerintah secara filosofis adalah untuk melayani kepentingan dan memenuhi kebutuhan rakyat. Pelayanan pemerintah yang berkualitas, sangat diperlukan guna mengimbangi peningkatan kondisi sosial, ekonomi serta kesadaran masyarakat dalam bernegara. Mekanisme penyelenggaraan pemerintahan dituntut untuk lebih efisien, efektif dan inovatif terutama dalam memberikan pelayanan kepada masyarakat, karena kebutuhan masyarakat semakin luas dan kompleks.

Dari hasil pengamatan selama ini menunjukkan bahwa layanan yang diberikan kepada warga masyarakat sering menimbulkan ketidaktertiban pelayanan, hal ini tampak dari banyaknya keluhan masyarakat. Dalam rangka mengefektifkan, meningkatkan, serta memperlancar pelayanan kepada masyarakat didalam mengurus perijinan, maka Pemerintah Daerah merasa perlu membentuk Unit Pelayanan Terpadu. Hal ini sesuai dengan Peraturan Menteri Dalam Negeri nomor 20 tahun 2008 tentang pedoman organisasi dan tata kerja unit pelayanan perizinan terpadu di daerah. Hal ini untuk menjawab keinginan masyarakat dalam mendapatkan pelayanan yang lebih baik pada bidang perizinan.

Implementasi kebiajkan pembentukan unit pelayanan terpadu yang didasari oleh aturan dan kebijakan publik mengharuskan implementor memperhatikan berbagai aspek yang berkaitan didalamnya guna keberhasilan dalam pelaksanaan. Secara etimologi, implementasiberasaldariistilahbahasaInggris "to implement", yang artinya pelaksanaan dan penerapan (Tachjan. 2006). Implementasi adalah melaksanakan sesuatu dalam hal ini kebijakan yang dapat menimbulkan sesuatu 
dampak tercapainya atau tidaknya sesuatu kebijakan dengan menggunakan sarana-sarana untuk melaksanakan kebijakan tersebut.

Jones (1994: 12) mengartikan implemntasi kebijakan sebagai "getting the job done and doing it". Penegertian ini merupakan pengertian yang sederhana, tetapi tidak berarti bahwa implementasi merupakan suatu proses kebijakan yang dapat dilaksanakan dengan mudah. Lebih lanjut Jones (1994 : 13) merumuskan batasan implementasi sebagai " a process off getting additional resources so as to figure out what is to be done". Dimana implemntasi kebijakan publik merupanan proses mendapatkan sumberdaya tambahan, sehingga dapat diperhitungkan apa yang harus dikerjakan. Pendapat Jones ini setidaknya mengisyaratkan dua bentuk tindakan yang berurutan. Pertama, merumuskan tindakan yang akan dilakukan. Kedua, melaksanakan tindakan apa yang telah dirumuskan tadi. Implementasi dimaksudkan bahwa keputusan yang dipilih oleh pemerintah dari berbagai alternatif kebijakan diterjemahkan kedalam tindakan.

Agar dapat terilmplementasi dengan baik apa yang menjadi tujuannya seperti yang telah dirumuskan maka kebijakan publik perlu dipersiapkan dengan baik. Keberhasilan implementasi kebijakan itu dapat dilihat dari beberapa aspek yang mempengaruhinya, yang oleh Charles $\mathrm{O}$. Jones (1996 : 296) mengemukakan bahwa terdapat tiga kegiatan yang menjadi pilar dalam implementasi kebijakan yaitu : 1). Organization; 2). Interpretation; 3). Aplication. Dalam pelaksanaannya, menurut Jones menuntut adanya syarat antara lain adanya orang atau pelaksana, uang dan kemampuan organisasional. Kemampuan organisasional yang dimaksudkan diarahkan pada kemampuan menginterpretasikan kebijakan yang ditetapkan sehingga dapat terimplementasi dengan baik.

Interpretasi (Interpretaton) merupakan aktivitas penterjemahan, penafsiran, penjelasan substansi dari suatu kebijakan dalam bahasa yang lebih operasional dan mudah dipahami, sehingga substansi kebijakan dapat dilaksanakan dan diterima oleh para pelaku dan sasaran kebijakan serta layak dilaksanakan. Interpretasi atas implementasi kebijakan pemberian izin mendirikan bangunan banyak diperhadapkan pada fenomena permasalahan baik dari para implementor maupun masyarakat yang melakukan pengurusan izin mendirikan bangunan.

Pertanyaan mendasar untuk digali lebih lanjut mengenai interpretasi dari implementor dalam pemberian Izin Mendirikan Bangunan (IMB) yang terlihat dari praktik perizinan melalui penyederhanaan prosedur dan ketentuan kelayakan pemberian izin. Kepemilikan bangunan sering menjadi sengketa publik yang berkepanjangan. Proses yang berbelit belit, lama, simpang siur prosedur pelayanan menjadi alasan masyarakat "malas" melakukan pengurusan Izin Mendirikan Bangunan.

Dalam prakteknya juga sering dijumlai adanya Izin Mendirikan Bangunan yang dikeluarkan tidak sesuai dengan ketentuan yang ada seperti memberikan izin mendirikan bangunan di lokasi rawan longsor, izin untuk rumah tinggal akan tetapi bangunannya adalah untuk usaha. Bahkan fenomena yang menarik bahwa tidak adanya pengawasan pasca pemberian izin mendirikan bangunan. Berbagai penelitian yang berkaitan dengan implementasi kebijakan izin mendirikan bangunan telah dilakukan seperti Kusnandar (2005), Rahima Erna (2010), Asep Sumaryana (2009) akan tettapi sebuah kenyataan menunjukkan fenomena permasalahan tersebut masih sering muncul yang bukan hanya di kota - kota besar akan tetapi menjadi permasalahan yang universal sampai ke kota kecil dan pelosok pedesaan. Penelitian iniberupaya mengeksplorasi aspek interpretasi dalam implementasi kebijakan pemberian izin mendirikan bangunan dengan menjadikan Kota Manado khususnya Badan Pelayanan Perizinan Terpadu sebagai lokasi penelitian. Melalui penelitian ini diharapkan dapat mengungkapkan makna dibalik permasalahan yang berkaitan dengan bagaimana aspek interpretasi dalam implementasi kebijakan pemberian izin mendirikan bangunan yang dilakukan oleh Badan Pelayanan Perizinan Terpadu Kota Manado. Melalui hasil penelitian ini peneliti 
berkeyakinan dapat memperkaya khasana keilmuan khususnya yang berkaitan dengan konsep teori implementasi kebijakan serta menjadi rekomendasi kepada stackholder dalam implementasi kebiajakan pemberian izin mendirikan bangunan.

\section{METODOLOGI PENELITIAN}

Penelitian ini menggunakan metode penelitian kualitatif, yaitu suatu penelitian kontekstual yang menjadikan manusia sebagai instrumen, dan disesuaikan dengan situasi yang wajar dalam kaitannya dengan pengumpulan data yang pada umumnya bersifat kualitatif melalui wawancara kepada sejumlah informan yang didukung dengan observasi dan studi dokumentasi (Creswell,1994).

Melalui desain ini dapat diperoleh gambaran fenomena, fakta, sifat serta hubungan fenomena tentang aspek interpretasi dalam implementasi kebijakan pemberian izin mendirikan bangunan yang termasuk didalamnya menyangkut penanganan akan prosedur perizinan secara utuh dan multidemensional sehingga dapat dilakukan kategorisasi dan jawaban atas perumusan masalah sebagai temuan penelitian.

\section{HASIL DAN PEMBAHASAN}

Berdasarkan data di Dinas Tata Kota dimana jumlah bangunan yang ada di kota manado per Desember 2010 sebanyak 77.886 buah, dengan posisi 30.685 buah yang telah memiliki izin mendirikan bangunan sementara 47.201 buah rumah belum memiliki izin pendirian. Dengan 47.201 buah rumah yang tidak memiliki izin pendirian serta kebutuahn rumah saat ini sebanyak 33.858 buah menunjukkan bahwa Badan Pelayanan Perizinan Terpadu Kota Manado memiliki beban tanggung jawab yang besar untuk dapat melakukan tindakan - tindakan pelayanan kepada masyarakat dalam pemberian izin mendirikan bangunan.

Pembentukan Badan Pelayanan Perizinan Terpadu merupakan wujud dari Grand Strategis Pembangunan Kota Manado yang dalam point pertama yaitu Manado Memiliki Kantor Pelayanan Satu Atap yang Memenuhi Standar Pelayanan Prima dalam melayani masyarakat yang didasarkan Peraturan Walikota Manado Nomor 40 Tahun 2008 tentang Rincian Tugas dan Fungsi Badan Pelayanan Perizinan Terpadu Kota Manado yang salah satu fungsinya adalah untuk melayani masyarakat dalam pelayanan izin mendirikan bangunan secara terpadu dengan prinsip koordinasi, integrasi, sinkronisasi, simplifikasi, keamanan dan kepastian.

Pengertian Interpretasi menurut Jones (1996 : 296) adalah "Menafsirkan agar program (serangkaian dalam status) menjadi rencana dan pengarahan yang tepat dan dapat diterima serta dilaksanakan". Jadi interpretasi berkait erat dengan para pelaksana (implementators) untuk memahami apa yang harus mereka kerjakan sesuai dengan yang seharusnya. Penafsiran yang keliru atau salah terhadap suatu kebijakan publik, akan mengakibatkan terjadinya kesalahan dalam implementasi kebijakan publik tersebut. Akibatnya tujuan dari kebijakan yang diimplementasikan tersebut tidak tercapai.

Pada rumusan interpretasi dalam pelaksanaan kebijakan ini menitikberatkan pada kejelasan, ketelitian, konsistensi, penyusunan prioritas, sumber daya yang cukup dan lain sebagainya. Dengan demikian, interpretasi terhadap setiap program dimaksudkan untuk lebih mengefektifkan pelaksanaannya, dan yang dapat memberikan pemahaman secara lengkap, tepat, dan jelas, sehingga memperlancar pelaksanaan program. Interpretasi dalam implementasi kebijakan pemberian izin mendirikan bangunan lebih diarahkan kepada bagaimana penyelenggara mengerti dan memahami akan pentingnya pemberian izin mendirikan bangunan dengan tidak melalaykan fungsi legalitas dan pelayanan yang berkualitas.

Kemampuan dari aparat yang telah dipercayakan dalam melayani masyarakat yang mengurus izin mendirikan bangunan yang terwujud dalam mengatur waktunya, menjabarkan program-program kerja, mengendalikan manajemen pemerintahan dan bahkan terkadang termasukjuga di-dalamnya permintaan-permintaan im-balan / biaya administrasi yang tidak wajar. Interpretasi yang benar terhadap suatu program dapat memudahkan implementasikan kebijakan. Sebaliknya kesalahan dalam interpretasi terhadap suatu program akan menyulitkan pelaksanaannya. 
Interpretasi ini dikaitkan dengan kepemimpinan, karena interpretasi ini mengkaji pengelolaan kebijakan, program dan kegiatan Badan Pelayanan Perizinan Terpadu yang akan dilaksanakan. Dalam pengambilan keputusan biasanya ada pada Pemerintah kota dalam hal ini melalui Kepala Badan Pelayanan Perizinan Terpadu Kota Manado. Hasil penelitian mengenai Interpretasi kebijakan Badan Pelayanan Perizinan Terpadu berdasarkan observasi dan pernyataan menunjukkan masih adanya hal-hal yang perlu untuk dilakukan perbaikan dalam upaya untuk mencapai tujuan yang ada dengan memberikan pelayanan yang terbaik kepada masyarakat baik dalam menginterpretasikan kebijakan, program dan kegiatan di badan pelayanan. Dalam dimensi Interpretasi yang dilakukan oleh pimpinan memiliki indikator kinerja sebagai pendukung dari keberhasilan program yang dilaksanakan yaitu: 1) Kebijakan, 2) Program dan 3) Kegiatan.

\section{Kebijakan}

Pada interpretasi yang mana pihak Badan Pelayanan Perizinan Terpadu Kota Manado dari pimpinan dan pegawai kantor perlu memberikan kebijakan di kantor dari program-program yang telah direncanakan. Kebijakan ini tidak lepas dari pengambilan keputusanberdasarkan peraturan perundangan yang berlaku. Badan Pelayanan Perizinan Terpadu Kota Manado selama ini telah melakukan interpretasi kebijakan berdasarkan peraturan yang berlaku dan juga pimpian kantor sering melakukan pengambilan kebijakan berdasarkan pertimbangan dan petunjuk dari pemerintah kota dengan memperhatikan segala potensi yang dimiliki oleh Badan Pelayanan Perizinan Terpadu Kota Manado tersebut.

Pemberian izin mendirikan bangunan setidaknya memiliki keterkaitan dengan berbagai kebijakan lainnya. Menjadi kewajiban Badan Pelayanan Perizinan Terpadu Kota Manado dalam hal ini pimpinan dan staf yang ada untuk dapat menginterpretasikan dengan baik dan benar segala kebijakan yang ada. Pemahaman yang benar terhadap segala peraturan yang berkaitan langsung dengan proses pemberian izin mendirikan bangunan akan memudahkan dalam pengeluaran izin.

Sebagai seorang pelayan masyarakat, pegawai yang ditempatkan di Badan Pelayanan Perizinan Terpadu Kota Manado diwajibkan untuk dapat mengerti dan memahami mengapa persyaratan tersebut dimintakan kepada masyarakat. Selain itu pula para pegawai diharapkan dapat memberikan solusi kepada masyarakat seandainya ada dokumen yang tidak dapat mereka penuhi.

Selain pemahamanterhadap persyaratan yang ada, proses mengeluarkan izin mendirikan bangunan erat kaitannya dengan berbagai kebijakan seperti halnya dengan memperhatikan tata letak bangunan dalam kaitan dengan garis sempadan, koefisien dasar bangunan, koefisien ketinggian bangunan, perhitungan retribusi serta dalam kaitannya dengan rencana tata ruang kota.

Ketaatan dan kepatuhan atas kebijakan yang ada mengharuskan adanya kondisi ketundukan penuh dan tidak ada penolakan sama sekali terhadap implementasi kebijakan pelayanan dalam proses pengurusan izin mendirikan bangunan. Untuk itu, diperlukan keteguhan sikap para pelaksana program dan semua pihak yang terkait untuk menumbuhkembangkan sikap patuh yang menyeluruh dan serentak. Apabila terdapat potensi penolakan dari kelompok-kelompok sasaran terhadap kebijakan maka harus diidentifikasi untuk dicarikan pemecahannya.

\section{Program}

Program kerja sebagai salah satu bentuk implementasi kebijakan. Program kerja yang dimiliki oleh Badan Pelayanan Perizinan Terpadu Kota Manado merupakan penjabaran atas tugas pokok dan fungsi yang ada sebagaimana Keputusan Walikota Manado nomor 44 tahun 2009. Program kerja yang dibuat memuat proses dan prosedur kerja, persyaratan, waktu pelaksanaan sampai pada perhitungan retribusi.

Mendukung rencana kerja, secara garis besar program rencana kerja diarahkan pada memenuhi strandar pelayanan prima. Untuk mencapai apa yang telah diprogramkan, sangat dibutuhkan kemampuan dari dari 
implemententor dalam melaksanakannya melalui berbagai kegiatan dengan dukungan sumber daya, sarana dan prasarana dan keuangan yang ada. Program merupakan rencana yang bersifat komprehensif yang sudah menggambarkan sumber daya yang akan digunakan dan terpadu dalam satu kesatuan. Program tersebut menggambarkan sasaran, ekbijakan, prosedur, metode, standar dan budget.

Menetapkan SDM pada bidangnya dalam pelaksanaan program merupakan langkayang dapatdilakukanagarpelaksanaan program dapat dilaksanakan dengan cepat dan berkualitas serta masyarakat dapat terlayani dengan baik. Selain itu diperlukan suatu tindakan dalam partisipasi terhadap program yang telah disusunnya atau direncanakan. Keterlibatan langsung dapat dilakukan melalui pengawasan langsung atas apa yang dilakukan oleh pegawai.

Kurangnya program yang berkaitan langsung dengan penerbitan izin mendirikan bangunan menurut pengamatan peneliti dilapangan karena tugas aparat tentang penerbitan izin mendirikan bangunan itu sendiri hanya bersifat memfasilitasi para pemohon. Karena sifatnya memfasilitasi tampaknya program penerbitan izin mendirikan bangunan tidak begitu prioritas. Sesungguhnya, meskipun itu hanya memfasilitasi program pemberian izin mendirikan bangunan harus disusun dengan baik, sebagai dasar untuk melakukan penilaian kinerja petugas pelayanan, demikian juga kesuksesan program harus diimbangi dengan sarana dan prasarana yang memadai. Sebab tanpa ketersediaan sarana untuk mencapai tujuan implementasi kebijakan penerbitan izin mendirikan bangunan dan aparatur tidak diperlengkapi dengan peralatan yang memadai untuk mencapai tujuan maka penerapan tujuan penerbitan izin mendirikan bangunan itu juga tidak optimal.

Sementara itu kurang konsistennya aparatur menjalankan program pemberian IMB, karena mereka tidak memiliki program yang jelas. Kurangnya konsistensi terhadap pemberian izin mendirikan bangunan ini membuat publik kurang termotivasi mengurus izinmendirikan bangunan. Bila diinterpretasikan kurang konsistennya aparatur terhadap penerbitan izin mendirikan bangunan ini menunjukkan kurang pentingnya penerbitan izin mendirikan bangunan dipahami publik. Kondisi ini tentu memberikan hasil yang minimal, tentang penerbitan izin mendirikan bangunan itu sendiri. Adanya konsistensi menjalankan program akan mempermudah untuk mengetahui tindakan-tindakan apa yang harus dilakukan, oleh siapa bilamana dan bagaimana melaksanakannya yang pada gilirannya penerbitan izin mendirikan bangunan akan semakin baik.

\section{Kegiatan}

Pelaksanaan kegiatan dalam upaya untuk dapat memberikan pelayanan yang terbaik kepada masyarakat melalui pemberian izinmendirikan bangunan denganmenetapkan persyaratan dan waktu penyelesaian dengan membagi habis kesembilan belas perizinan dalam empat bidang. Permasalahan yang paling banyak menjadi sorotan dalam pelayanan Badan Pelayanan Perizinan Terpadu Kota Manado adalah ketidak tepatan dalam waktu penyelesaian izin. Banyaknya permohonan yang menumpuk mengakibatkan terjadinya penumpukan beban kerja.

Segala keterbatasan yang ada baik dalam hal keterbatasan sumber daya manusia (kekuarangan personil), keterbatasan sarana kantor serta tidak tertatanya dengan baik struktur organisasi dimana tim teknis langsung berada di bawah Dinas tertentu tidak langsung dibawah Badan Pelayanan Perizinan Terpadu, menjadi tanggung jawab yang besar bagi kepala badan dalam kinerjanya selalu memberikan motivasi dan mewawancari staf, untuk melihat seberapa jauh kinerja yang telah dilaksanakan termasuk hambatan - hambatan yang dihadapi dalam pemberian pelayanan. Hal ini dilakukan untuk meningkatkan kualitas pemberianizin mendirikan bangunan pada Badan Pelayanan Perizinan Terpadu Kota Manado sebagai pihak penyelengara perizinan.

Kegiatan pelayanan izin mendirikan bangunan diawali dengan kehadirannya masyarakat yang akan mengurus izin mendirikan bangunan yang datang ke Badan Pelayanan Perizinan Terpadu Kota Manado. Sebagaimana skema proses pelayanan, pemohon akan langsung diarahkan oleh 
customer service ke loket pelayanan yang dalam hal ini untuk izin mendirikan bangunan ke loket dua. Diloket dua tersebut petugas yang telah siap untuk melayanai masyarakat melayani masyarakat dengan memberikan penjelasan, memeriksa dan mengarahkan masyarakat tersebut. Berkas yang telah dimasukkan, oleh pegawai diloket tersebut dibawah ke petugas pemeriksa yang selanjutnya diserahkan ke tim pemeriksa lapangan. Ketika selesai pemeriksaan dan dianalisis layak untuk dikeluarkan izin maka masyarakat tersebut diberikan izin untuk mendirikan bangunan dengan terlebih dahulu diwajibkan untuk membayar retribusi. Proses kerja ini ditetapkan oleh Badan Pelayanan Perizinan Terpadu Kota Manado dalam jangka waktu kerja 10 hari kerja.

Kenyataan yang terjadi seperti informasi yang diperoleh dari masyarakat dimana penyelesaian dalam penerbitan izin mendirikan bangunan lebih dari 10 hari bahkan ada yang lebih fatal lagi dimana ada yang sudah lebih dari 60 hari belum selesai juga permohonan izin mendirikan bangunannya. Kenyatan inilah yang sebenarnya memerlukan perhatian dari pimpinan Badan Pelayanan Perizinan Terpadu Kota Manado dalam interpretasi kebijakan pembentukan Badan Pelayanan Perizinan Terpadu Kota Manado. Badan Pelayanan Perizinan Terpadu Kota Manado dibentuk dengan harapan akan dapat memberikan pelayanan dalam bidang perizinan dengan cepat, mudah, transparan dan pasti.

Penyelesaian waktu yang melebihi waktu yang telah ditetakan yang ditambah dengan tidak transparannya biaya yang harus dibayar memberikan penilaian negatif dari masyarakat atas apa yang dilakukan oleh Badan Pelayanan Perizinan Terpadu Kota Manado. Interpretasi yang tepat dan benar akan dapat mengindarkan segala penilaian negative dari masyarakat kepada pemerintah.

Berkenaan dengan masih berbelitbelitnya proses dan prosedur pemohonan ijin mendirikan bangunan, dan lamanya waktu yang diperlukan tersebut akan menimbulkan ekses yang kurang baik di lapangan. Baik dalamkaitannyadengan penilaianmasyarakat akan kinerja pemerintah, penataan bangunan kota sampai pada menumpuknya pekerjaan dari pemerintah khususnya dalam pelayanan izin mendirikan bangunan.

Ketepatan dalam proses implementasi tidak dapat dipisahkan dari kemampuan para implementor dalam memahami kebijakan yang ada melalui tugas dan tanggung jawab yang diberikan. Kemampuan aparat selaku implementor kebijakan pelayanan perizinan terpadu akan terlihat dari kemampuan dalam merencanakan, melaksanakan, memimpin, maupun bersikap.

Kemampuan dalam kaitannya dengan ilmu administrasi publik khususnya studi sember daya manusia sering disebut kompetensi. Sumber daya manusia yang berada pada suatu organisasi akan sangat menentukan kinerja organisasi tersebut. Jika sumber daya manusia tersebut memiliki motivasi tinggi, kreatif dan inovatif, kinerjanya akan semakin baik, oleh karena itu diperlukan suatu upaya untuk meningkatkan kemampuan sumber daya manusia yang menyangkut kemampuan intektual melalui peningkatan pengetahuan, peningkatan ketrampilan melalui pelatihan dan praktek serta perbaikan prilaku dalam melaksanakan tugas.

\section{SIMPULAN}

Berdasarkan hasil penelitian dan pembahasan bahwa aspek interpretasi dalam implementasi pemberian izin mendrikan bangunan pada Badan Pelayanan Perizinan TerpaduKota Manado berkaitan dengan indikator pemaknaan atas kebijakan, program dan kegiatan. Interpretasi dalam pemberian izin mendirikan bangunan di kota Manado terlihat dari mudah tidaknya aparatur memahami isi kebijakan itu. Adanya kemudahan aparatur menginterpretasi isi kebijakan itu akan sangat berkaitan dengan kualitas sumber daya yang dimiliki baik dari pendidikan, pengalaman, keahlian oleh para implementor.

Kebutuhan utama bagi pelaksanaan kebijakan adalah bahwa implementor harus mengetahui secara jelas apa yang seharusnya dilakukan, mereka harus memiliki cara pandang yang sama terhadap isi kebijakan. Jika kebijakan ingin dilaksanakan dengan tepat, arahan, dan petunjuk pelaksanaan 
tidak hanya diterima tetapi juga harus jelas. Jika masih terjadi ketidakjelasan mengenai apa yang seharusnya dilakukan implementor akan membuat mereka kebingungan, sehingga pada akhirnya mereka bertindak berbeda dengan pandangan dari atasan mereka, atau bahkan membuat kebijakan sendiri.

Dalam pemberian izin mendirikan bangunan aparat memiliki kewajiban untuk menginterpretasikan atau memahami isi kebijakan yang ada. Ada tidaknya kesulitan aparat dalam menginterpretasikan kebijakan penerbitan izin mendirikan bangunan akan sangat tergantung pada kualitas sumber daya dari aparat itu sendiri. Interpretasi kebijakan penerbitan izin mendirikan bangunan itu sudah dipahami namun tidak serta merta dapat mempercepat penerbitan izin mendirikan bangunan, karena itu masih perlu pemahaman itu lebih dipertegas lagi. Sebab, apabila masih ada penafsiran yang berbeda di antara sesama pegawai terhadap isi kebijakan penerbitan izin mendirikan bangunan itu, maka isi kebijakan itu akan sulit dilaksanakan (diterapkan).

Agar implementasi kebijakan pemberian izin mendirikan bangunan itu berhasil perlu dipahami dimensi interpretasi itu dengan baik, sebab interpretasi akan dapat memperjelas pelaksanaan kebijakan itu sendiri. Artinya semakin baik interpretasi aparatur terhadap isi kebijakan itu maka akan semakin efektif pula pemberian izin mendirikan bangunan di kota Manado.

\section{DAFTAR PUSTAKA}

Asep Sumaryana. 2009. Pengaruh Lingkungan Sosial dan Lingkungan Kerja Terhadap Efektivitas Implementasi Rencana Tata Ruang Wilayah (RTRW) di Kota Bandung
(Studi Mengenai Pemanfaatan Ruang di Wilayah Bandung Utara). Program Pascasarjana Unpad : Bandung.

Creswell, John W. 1994. Qualitative Inquiry and Reasearch Disign. Sage. California.

Jones, Charles O. 1996. An Introduction To The Study of Public Policy, diterjemahkan oleh Ricky Irianto, Cet 3. Jakarta : RajaGrafindo Persada.

Ishak Kusnandar H. 2005. Pengaruh Implementasi Kebijakan terhadap Kualitas Pelayanan Izin Mendirikan Bangunan. Program Pascasarjana Unpad : Bandung.

Peraturan Menteri Dalam Negeri nomor 20 tahun 2008 tentang pedoman organisasi dan tata kerja unit pelayanan perizinan terpadu di daerah.

Peraturan Daerah Kota Manado Nomor 08 Tahun 2000 tentang Izin Mendirikan Bangunan

Peraturan walikota Manado nomor 6 tahun 2009 tentang penyelenggaraan perizinan pada Badan Pelayanan Perizinan Terpadu (BPPT) Kota Manado

Rahima Erna. 2010. Pengaruh Implementasi Kebijakan Pelimpahan Kewenangan Terhadap Kualitas Pelayanan Publik (Studi Tentang Pelayanan Izin Mendirikan Bangunan oleh Pemerintah Kecamatan di Kota Pekan Baru Provinsi Riau) . Program Pascasarjana Unpad : Bandung.

Tachjan. 2006. Implementasi Kebijakan Publik. Bandung: AIPI Bandung Puslit KP2W Lemlit Unpad. 